\title{
77. Frequencies of Rh and Kidd Blood Types and Private and Public Antigens among the Japanese
}

\author{
By Tanemoto Furuhata, ${ }^{*)}$ M.J.A., Hachiro Nakajima, ${ }^{*}$ ) \\ Shigenori Iкемото, ${ }^{*)}$ and Hideo Nagata*) \\ (Comm. June 12, 1961)
}

Up to date, more than thirty different blood groups have been discovered; but, aside from the $\mathrm{ABO}, \mathrm{MN}$, and $\mathrm{Q}$ groups, and the secretor character, few studies have been made on the frequencies of these groups among Japanese people. On the Kidd blood groups, we have only one report made by Nakajima (1961), ${ }^{1}$ but none on the public or private antigens, $\mathrm{Vel}, \mathrm{I}, \mathrm{Wr}^{\mathrm{a}}$, and $\mathrm{Sw}^{\mathrm{a}}$.

Our studies have been carried out on the frequency of blood groups, Vel, I, $\mathrm{Wr}^{\mathrm{a}}$, and $\mathrm{Sw}^{\mathrm{a}}$, as well as of the $\mathrm{Rh}$ and Kidd blood groups among the Japanese living in Tokyo.

Materials and methods. The blood samples were taken at random from staff members of the Scientific Police Research Institute and of the Tokyo Medical and Dental University, as well as from donors to the Nihon Seiyaku Blood Bank. These samples were tested by using the following antisera:-

1) the anti- $\mathrm{C}\left(\mathrm{rh}^{\prime}\right)$, anti-c $\left(\mathrm{hr}^{\prime}\right)$, anti- $\mathrm{D}\left(\mathrm{Rh}_{0}\right)$, anti-E( $\left(\mathrm{rh}^{\prime \prime}\right)$, and anti$\mathrm{e}\left(\mathrm{hr}^{\prime \prime}\right)$ for $\mathrm{Rh}$ blood groups

2) the anti-Jk ${ }^{a}$ and anti-Jk $\mathrm{K}^{\mathrm{b}}$ for Kidd blood groups

3) the anti-Vel, anti-I, anti-Wra ${ }^{\mathrm{a}}$, and anti-Swa for other groups.

The anti-C, anti-Jk ${ }^{\mathrm{a}}$, anti-Jk ${ }^{\mathrm{b}}$, anti-Vel, anti-I, and anti-Sw ${ }^{\mathrm{a}}$ were available through the kindness of Dr. F. H. Allen, while the anti-Wri was kindly supplied by Dr. F. H. Allen and Dr. J. F. Mohn of the University of Buffalo.

The other antisera were obtained from Ortho Pharmaceutical Corporation, New Jersey, and were used according to the directions.

Results. 1) Rh groups: 167 blood samples were tested with the five antisera, anti-C, anti-c, anti-D, anti-E, and anti-e. The result is shown in Table I.

For estimating the frequency of chromosomes carrying Rh genes among the Japanese, samples are too few, and we compared our results with the data given by Nakajima (1961), ${ }^{1)}$ who had examined citizens of Tokyo for the same purpose. Since no significant difference was found between these two samples, calculation was made on the above two combined data. The calculation was carried on by method of

*) Scientific Police Research Institute.

**) Department of Legal Medicine, Tokyo Medical and Dental University. 
Table I. Rh groups (tested with anti-C, -c, -D, -E, and -e)

\begin{tabular}{|c|c|c|c|c|c|c|c|c|}
\hline \multirow{2}{*}{$\begin{array}{r}\text { Population } \\
\text { Phenotype }\end{array}$} & \multicolumn{2}{|c|}{$\begin{array}{l}\text { Japanese } \\
\left(\begin{array}{c}\text { Present } \\
\text { study }\end{array}\right)\end{array}$} & \multicolumn{2}{|c|}{$\begin{array}{c}\text { Japanese } \\
\left(\begin{array}{c}\text { Nakajima, } \\
\text { 61 }\end{array}\right)^{1)}\end{array}$} & \multicolumn{2}{|c|}{$\begin{array}{c}\text { Japanese } \\
\left(\begin{array}{c}\text { Furuhata } \\
\text { et al., '54 }\end{array}\right)\end{array}$} & \multicolumn{2}{|c|}{$\begin{array}{c}\text { Japanese } \\
\left(\begin{array}{l}\text { Noda and } \mathrm{Ha} a \\
\text { yakawa, ' } 60\end{array}\right)^{33}\end{array}$} \\
\hline & No. & $\%$ & No. & $\%$ & No. & $\%$ & No. & $\%$ \\
\hline CCDee & 74 & 44.31 & 79 & 42.93 & 383 & 45.06 & 1402 & 43.38 \\
\hline $\begin{array}{l}\text { CCDEe } \\
\text { CCDEE }\end{array}$ & $\begin{array}{l}1 \\
0\end{array}$ & $\begin{array}{l}0.60 \\
0.00\end{array}$ & $\begin{array}{l}0 \\
0\end{array}$ & $\begin{array}{l}0.00 \\
0.00\end{array}$ & 27 & 3.18 & 419 & 12.96 \\
\hline $\begin{array}{l}\text { CcDEe } \\
\text { CcDEE }\end{array}$ & $\begin{array}{r}59 \\
0\end{array}$ & $\begin{array}{r}35.33 \\
0.00\end{array}$ & $\begin{array}{r}65 \\
0\end{array}$ & $\begin{array}{r}35.33 \\
0.00\end{array}$ & 264 & 31.06 & 774 & 23.94 \\
\hline CcDee & 10 & 5.99 & 16 & 8.70 & 58 & 6.82 & 330 & 10.22 \\
\hline $\begin{array}{l}\text { ccDEe } \\
\text { ccDEE }\end{array}$ & $\begin{array}{r}13 \\
8\end{array}$ & $\begin{array}{l}7.78 \\
4.79\end{array}$ & $\begin{array}{r}2 \\
16\end{array}$ & $\begin{array}{l}1.09 \\
8.70\end{array}$ & 98 & 11.53 & 261 & 8.07 \\
\hline ccDee & 0 & 0.00 & 1 & 0.54 & 8 & 0.97 & 19 & 0.59 \\
\hline CCdee & 0 & 0.00 & 0 & 0.00 & 0 & 0.00 & 6 & 0.19 \\
\hline Ccdee & 0 & 0.00 & 1 & 0.54 & 0 & 0.00 & 0 & 0.00 \\
\hline $\begin{array}{l}\text { CcdEe } \\
\text { CcdEE }\end{array}$ & $\begin{array}{l}0 \\
0\end{array}$ & $\begin{array}{l}0.00 \\
0.00\end{array}$ & $\begin{array}{l}0 \\
0\end{array}$ & $\begin{array}{l}0.00 \\
0.00\end{array}$ & 1 & 0.12 & 3 & 0.09 \\
\hline c'cdee & 1 & 0.60 & 2 & 1.09 & 3 & 0.35 & 7 & 0.22 \\
\hline $\begin{array}{l}\text { ccdEe } \\
\text { ccdEE }\end{array}$ & $\begin{array}{l}0 \\
1\end{array}$ & $\begin{array}{l}0.00 \\
0.60\end{array}$ & $\begin{array}{l}1 \\
1\end{array}$ & $\begin{array}{l}0.54 \\
0.54\end{array}$ & 8 & 1.94 & 11 & 0.34 \\
\hline Total & 167 & & 184 & & 850 & & 3232 & \\
\hline
\end{tabular}

Table II. Frequencies of the $\mathrm{Rh}$ chromosomes

\begin{tabular}{|c|c|c|c|c|c|c|c|c|c|}
\hline & Population & $\begin{array}{c}\text { Number } \\
\text { tested }\end{array}$ & cde & Cde & $c d E$ & $c D e$ & $C D e$ & $C D E$ & $c D E$ \\
\hline a) & $\begin{array}{l}\text { Japanese } \\
\text { (Present study) }\end{array}$ & $351 *$ & $* 0.0630$ & 0.0226 & 0.0759 & 0.0097 & 70.6298 & 80.0014 & 0.1976 \\
\hline b) & $\begin{array}{l}\text { Japanese } \\
\text { (Furuhata et al., '54) }\end{array}$ & 850 & 0.0594 & 10.0000 & 0.0543 & 0.0543 & 30.6712 & 0.0233 & 0.1375 \\
\hline c) & $\begin{array}{l}\text { Japanese } \\
\text { (Noda and Hayakawa, }\end{array}$ & 3232 & 0.0469 & 0.0171 & 0.0279 & 0.0431 & 0.6429 & 90.0918 & 0.1303 \\
\hline d) & $\begin{array}{l}\text { Koreans } \\
\text { (Chong et al., ' } 60)^{4)}\end{array}$ & 387 & 0.0000 & 0.0000 & 0.0000 & 0.0573 & 0.6197 & 70.0082 & 0.3148 \\
\hline e) & $\begin{array}{l}\text { Southern Chinese } \\
\text { (Simmons et al., '50)' }\end{array}$ & 250 & 0.0000 & 0.0000 & 0.0000 & 0.0409 & 0.7591 & 10.0049 & 0.1951 \\
\hline f) & $\begin{array}{l}\text { English } \\
\left.\text { (Race and Sanger, ' } 58)^{6}\right)\end{array}$ & 2000 & 0.3886 & 0.0098 & 0.0119 & 0.0257 & 0.4076 & 0.0024 & 0.1411 \\
\hline g) & $\begin{array}{l}\text { American Whites } \\
\text { (Wiener et al., ' } 52)^{7)}\end{array}$ & 743 & 0.4109 & 0.0045 & 0.0036 & 0.0260 & 0.4165 & 0.0015 & 0.1369 \\
\hline h) & 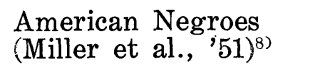 & 200 & 0.2338 & 0.0107 & 0.0000 & 0.4850 & 0.1593 & 30.0000 & 0.1121 \\
\hline
\end{tabular}

Method of calculation:

a) d) Mourant's method

b) c) Fisher's simpler method

f) Fisher's maximum likelihood method

* Including the 184 blood samples previously tested by Nakajima ('61).

Mourant (1954), , $^{\text {) }}$ with the kind co-operation of Prof. K. Tanaka of the Department of Human Genetics of the Tokyo Medical and Dental University. The result is shown in Table II. It is to be noted that 
the frequency of cde chromosomes among the Japanese is much lower than that among American Whites or among English people, while the frequency of $C D e$ chromosomes is higher than among these white people.

2) Kidd groups: 100 blood samples were tested, using the anti$\mathrm{Jk}^{\mathrm{a}}$ and anti-Jk ${ }^{\mathrm{b}}$ sera. Table III shows that the frequency of the $\mathrm{Jk}^{\mathrm{a}}$ among Japanese is lower than that among English, while the frequency of the $\mathrm{Jk}^{\mathrm{b}}$ is higher.

Table III. Kidd groups (tested with anti-Jk ${ }^{\mathrm{a}}$ and $-\mathrm{Jk}^{\mathrm{b}}$ )

\begin{tabular}{|c|c|c|c|c|c|c|c|c|c|c|}
\hline \multirow{3}{*}{ Population } & \multirow{3}{*}{$\begin{array}{c}\text { Number } \\
\text { tested }\end{array}$} & \multicolumn{6}{|c|}{ Phenotype } & \multicolumn{3}{|c|}{ Gene frequency } \\
\hline & & \multicolumn{2}{|c|}{$J k(a+b-)$} & \multicolumn{2}{|c|}{$\mathrm{Jk}(\mathrm{a}+\mathrm{b}+)$} & \multicolumn{2}{|c|}{$\mathrm{Jk}(\mathrm{a}-\mathrm{b}+)$} & \multirow{2}{*}{$J k^{a}$} & \multirow{2}{*}{$J k^{b}$} & \multirow{2}{*}{$\sigma$} \\
\hline & & No. & $\%$ & No. & $\%$ & No. & $\%$ & & & \\
\hline $\begin{array}{l}\text { Japanese } \\
\text { (Present study) }\end{array}$ & 100 & 15 & 15.00 & 44 & 44.00 & 41 & 41.000 & 0.3700 & 0.6300 & 0.0346 \\
\hline $\begin{array}{l}\text { Japanese } \\
\text { (Nakajima, '61) }^{1)}\end{array}$ & 51 & 9 & 17.65 & 23 & 45.10 & 19 & $37.25 c$ & 0.4020 & 0.5980 & 0.0490 \\
\hline $\begin{array}{l}\text { English } \\
\text { (Race and Sanger, '58) }\end{array}$ & 275 & 75 & 27.27 & 139 & 50.55 & 61 & 22.88 & 0.5255 & 0.4745 & 0.0212 \\
\hline $\begin{array}{l}\text { New York Negroes } \\
\text { (Race and Sanger, '58) }^{6}\end{array}$ & 67 & 38 & 56.72 & 23 & 34.33 & 6 & 8.950 & 0.7389 & 0.2611 & 0.0374 \\
\hline
\end{tabular}

3) $\mathrm{Wr}^{\mathrm{a}}$ and $\mathrm{Sw}^{\mathrm{a}}$ antigens: 217 blood samples were tested with the anti-Wra and anti-Sw ${ }^{\mathrm{a}}$ sera, but all the blood samples showed negative reaction (Tables IV and V).

Table IV. Wra antigen

\begin{tabular}{|c|c|c|c|c|c|}
\hline \multirow{2}{*}{ Population } & \multirow{2}{*}{$\begin{array}{c}\text { Number } \\
\text { tested }\end{array}$} & \multicolumn{2}{|c|}{$\mathrm{Wr}(\mathrm{a}+)$} & \multicolumn{2}{|c|}{$\mathrm{Wr}(\mathrm{a}-)$} \\
\hline & & No. & $\%$ & No. & $\%$ \\
\hline $\begin{array}{l}\text { Japanese } \\
\text { (Present study) }\end{array}$ & 217 & 0 & 0.00 & 217 & 100.00 \\
\hline $\begin{array}{l}\text { English } \\
\quad\left(\text { Holman, }^{\prime} 53\right)^{10)}\end{array}$ & 1004 & 0 & 0.00 & 1004 & 100.00 \\
\hline $\begin{array}{l}\text { English } \\
\quad \text { (Cleghorn, ' } 60)^{12)}\end{array}$ & 31522 & 24 & 0.08 & 31498 & 99.93 \\
\hline $\begin{array}{l}\text { Dutchmen } \\
\quad \text { (van Loghem et al., '55) }{ }^{11)}\end{array}$ & 5000 & 15 & 0.30 & 4985 & 99.70 \\
\hline $\begin{array}{l}\text { Glaswegians } \\
\quad(\text { Wallace and Milne, ' } 56)^{14)}\end{array}$ & 1000 & 1 & 0.10 & 999 & 99.90 \\
\hline
\end{tabular}

Table V. Swa antigen

\begin{tabular}{c|c|cr|rr}
\hline \multirow{2}{*}{ Population } & \multirow{2}{*}{$\begin{array}{c}\text { Number } \\
\text { tested }\end{array}$} & \multicolumn{2}{|c|}{ Sw(a+) } & \multicolumn{2}{|c}{ Sw(a-) } \\
\cline { 3 - 6 } & No. & $\%$ & \multicolumn{2}{|c}{ No. } & $\%$ \\
\hline Japanese (Present study) & 217 & 0 & 0.00 & 217 & 100.00 \\
English (Cleghorn, '60) ${ }^{12)}$ & 31522 & 5 & 0.02 & 31517 & 99.98 \\
\hline
\end{tabular}


4) Vel antigen: As the anti-Vel serum used by us contained the anti-A and anti-B agglutinins, only the $\mathrm{O}$ blood cells were tested. We were unable to test many blood samples. All the 42 samples tested showed positive reactions, and no case of Vel negative was found (Table VI).

Table VI. Vel antigen

\begin{tabular}{l|r|rr|rr}
\hline \multirow{2}{*}{ Population } & Number & \multicolumn{2}{|c|}{ Vel } & \multicolumn{2}{|c}{ Vel - } \\
\cline { 3 - 5 } & tested & No. & $\%$ & No. & $\%$ \\
\hline $\begin{array}{c}\text { Japanese } \\
\quad \text { (Present study) }\end{array}$ & 42 & 42 & 100.00 & 0 & 0.00 \\
$\begin{array}{c}\text { American Whites } \\
\quad(\text { Sussman and Miller, '52) })^{13)}\end{array}$ & 10000 & 9996 & 99.96 & 4 & 0.04 \\
$\begin{array}{c}\text { American Negroes } \\
\text { (Sussman and Miller, '52) }\end{array}$ & 200 & 200 & 100.00 & 0 & 0.00 \\
\hline
\end{tabular}

5) I antigen: 145 blood samples were tested, using the anti-I serum. No I-negative blood cells were found, all being positive.

Summary. Studies were carried out on the frequencies of the $\mathrm{Rh}$ and Kidd blood groups as well as of the $\mathrm{Wr}^{\mathrm{a}}, \mathrm{Sw}^{\mathrm{a}}$, Vel, and I antigens among residents in Tokyo. It has been found that of the Rh group the frequency of $c d e$ chromosomes is much lower than among English or American Whites, while the frequency of $C D e$ chromosomes is somewhat higher than among the latter. Our study of the Kidd groups has shown that the frequency of the $\mathrm{Jk}^{\mathrm{a}}$ factor among the Japanese is lower than that among the English.

Our examination has revealed no case of Vel negative, I negative, nor of $\mathrm{Wr}^{\mathrm{a}}$ and $\mathrm{Sw}^{\mathrm{a}}$ positive.

(We express our deep appreciation to Dr. Fred H. Allen and Dr. J. F. Mohn who have kindly supplied us with the precious antisera used for the present study.)

\section{References}

1) Nakajima, H.,: Distribution of the MNSs, Kell, Duffy, Kidd and Rh blood groups among the Japanese, Jap. J. Legal Med., 15(4), 1(1961), in the press.

2) Furuhata, T., Uetake, M., and Yokoyama, M.,: The frequency of the Rh-Hr blood types in Japanese, Proc. Japan Acad., 30(7), 655-659 (1954).

3) Noda, K., and Hayakawa, Z.,: The frequency of the Rh groups in Japanese random blood samples, 8th Congress of the International Society of Blood Transfusion, 11-a-16 (1960).

4) Chong Duk Won, Han Su Shin, et al.: Distribution of hereditary blood factors among Koreans residing in Seoul, Korea, Am. J. Phys. Anthrop., 18(2), 115124 (1960).

5) Simmons, R. T., Graydon, J. J., Semple, N. M., and Green, R.,: The $A_{1}-A_{2}-B-O$, $\mathrm{M}-\mathrm{N}$ and Rh boold groups in southern Chinese; Hak-Kas, Cantonese and Hokkas, 
Med. J. Anat., 11, 917-922 (1950), cited from Chong et al.

6) Race, R. R., and Sanger, R.,: Blood Groups in Man, Oxford, Blackwell, 3rd ed., 132, 228, 236 (1958).

7) Wiener, A. S., Gordon, E. B., and Cohen, L.,: A new rare Rhesus agglutinogen, Am. J. Hum. Genet., 4, 363-372 (1952).

8) Miller, E. B., Rosenfield, R. E., and Vogel, P.,: On the incidence of some of the new blood agglutinogens in Chinese and Negroes, Am. J. Phys. Anthrop., 9, 115-126 (1951).

9) Mourant, A. E.,: The Distribution of the Human Blood Groups, Springfield, Thomas, 1st ed., 222-228 (1954).

10) Holman, C. A.,: A New Rare Human Blood-group Antigen (Wra), Lancet, 265, 119-120 (1953).

11) van Loghem, J. J., van der Hart, Mia., Bok, J., and Brinkerink, P. C.,: Two further examples of the antibody anti-Wr (Wright), Vox Sang., 5(4-5), 130134 (1955).

12) Cleghorn, T. E.,: The frequency of the $\mathrm{Wr}^{\mathrm{a}}$, By and $\mathrm{M}^{\mathrm{g}}$ blood group antigens in blood donors in the south of England, Vox Sang., 5(6), 556-560 (1960).

13) Sussman, L. N., and Miller, E. B.,: Un nouveau facteur sanguin "Vel", Rev. Hemat., 7, 368-371 (1952), cited from Race and Sanger.

14) Wallace, J., and Milne, G. R.,: Personal communication to Dr. Race, R. R., and Sanger, R. (cited from Race and Sanger, 1958). 